\title{
The Effect of Supplementary Feeding on the Reproductive Performance of Beef Cows in Supporting the Siwab Program
}

\author{
Agung Prabowo', Subiharta, Pita Sudrajad, Iswanto, Sularno, Budi Utomo \\ ${ }^{1}$ Balai Pengkajian Teknologi Pertanian Jawa Tengah \\ Coresponding author: agungsuwarjo@gmail.com
}

\begin{abstract}
This study aimed to determine the effect of supplementary feeding on the reproductive performance of beef cattle and calf birth weight. Additional feed was given to pregnant beef cows (8-9 months) and after giving birth for 3 months. The additional feed provided is in the form of complete feed prepared from local feed ingredients. The purpose of this supplementary feeding, namely: maintaining the condition of the parent's body, maintaining normal embryo growth, and accelerating postpartum estrus. Fifteen pregnant cows (8-9 months) were used in this study. The cows were divided into three treatments, namely: I. Group of cows that were given additional feed formulations I, II. Group of cows that were given supplementary feed formulations II, and III. Group of cows that were not given additional feed. Each treatment consisted of five replications. The research was conducted in Megal Village, Pamotan District, Rembang Regency. Giving additional feed of $5 \mathrm{~kg} / \mathrm{head} /$ day to pregnant beef cows and after giving birth for 3 months can suppress the decrease in body weight of beef cattle when the availability of feed is limited, increase calf birth weight, and accelerate postpartum estrus (first estrus after birth). Supplementary feeding to pregnant beef cows and after giving birth is highly recommended, especially for areas with fluctuating feed availability.
\end{abstract}

Key words: supplementary feed, reproduction, beef cattle cows

\section{Introduction}

The Ministry of Agriculture in 2016 issued the Regulation of the Minister of Agriculture of the Republic of Indonesia Number 48/Permentan/PK.210/10/2016 concerning Special Efforts to Accelerate the Increase of Pregnant Cattle and Buffalo Populations, hereinafter referred to as Upsus Siwab (special efforts for pregnant cows). The acceleration of the population increase is carried out to meet the need for food of animal origin and is carried out through artificial insemination (AI) or natural mating by implementing a reproductive management system. Supplementary feeding is one of the activities to support the acceleration of population increase. Beef cows that are pregnant and after giving birth are recommended to be given additional feed, especially during the dry season because forage is very limited. Additional feed will certainly help the reproductive status of the beef cows remain normal so that the beef cows after giving 
birth can return to estrus immediately. In addition, birth weight and calf growth can be maximized.

Supplementary feed is feed given to livestock in a certain amount other than the usual feed given every day for a specific purpose. Provision of additional feed for beef cows that are pregnant (8-9 months) and after giving birth (2-3 months) aims to: 1). maintain the condition of the parent body in order to remain in good condition, 2). maintain normal growth of the embryo (calf candidate), 3). optimize the production of mother's milk for normal calf growth, 4). accelerate the return of estrus after giving birth so that they can give birth once a year. The supplementary feed provided can be either a single feed or a complete feed. Single feed can be bran, rice bran, pollard, corn bran, and tofu dregs. Meanwhile, complete feed is a mixture of feed ingredients as sources of energy, protein, minerals, and vitamins so that the nutrient content of the feed becomes complete and sufficient to meet the needs of livestock.

Feed is given to livestock according to their physiological status. The feed of pregnant beef cattle is certainly different from that of non-pregnant cows, both in terms of quantity and nutrient content. Good feed is one that meets the needs of livestock so that livestock can live normally. Complete feed is better than single feed because it is composed of several feed ingredients so that the nutrients contained in it are complete and sufficient to meet the needs of livestock, while single feed usually contains nutrients that are below the needs of livestock so that if given to livestock it must be added with feed ingredients that so that the feed provided can meet the needs of livestock. Each single feed when viewed from its nutrient content has advantages and disadvantages so that single feeds can be grouped into feed sources of protein, carbohydrates, minerals, and vitamins.

This study aimed to determine the effect of supplementary feeding on the reproductive performance of beef cattle and calf birth weight. Additional feed was given to pregnant beef cows (8-9 months) and after giving birth for 3 months. The additional feed provided is in the form of complete feed prepared from local feed ingredients.

\section{Materials and Methods}

\section{Location and Time}

This activity was carried out in Megal Village, Pamotan District, Rembang Regency. The implementation time of the activity is from June to December 2019.

\section{Tools and materials}

The equipment used is feed and livestock scales, drums, choppers, shovels, and measuring tapes. The materials used are: bran, odot and elephant grass, gliricidia, corn stover, rice straw, molasses, table salt, starter, mineral mix, and clean water.

\section{Materials}

The material used in this study, namely 15 beef cows who were in an old pregnant condition (8-9 months).

\section{Research Design}

This activity consisted of three treatment groups, namely:

1) Group I, beef cows fed with formulation I supplementary feed,

2) Group II, beef cows fed with formulation II supplementary feed,

3) Group III, beef cows that were not given additional feed. 
Each treatment group consisted of five replications. The supplementary feed provided is in the form of complete feed with the following formulation:

Table 1. Types and composition of ingredients for complete feed periods I and II

\begin{tabular}{|c|c|c|c|c|}
\hline \multirow{2}{*}{ Feed Ingredients } & \multicolumn{2}{|c|}{ Periods I } & \multicolumn{2}{|c|}{ Periods II } \\
\hline & Formulation I & Formulation II & Formulation I & Formulation II \\
\hline 1. Elephant grass (\%) & 25 & - & 10 & - \\
\hline 2. Field grass $(\%)$ & - & 36 & - & - \\
\hline 3. Jaranan leaves $(\%)$ & 16 & 13 & - & - \\
\hline 4. Sugarcane (\%) & - & - & 28 & 38 \\
\hline 5. Gliricidia leaves $(\%)$ & 10 & 9 & 32 & 32 \\
\hline 6. Fresh Straw (\%) & 36 & 31 & 15 & 15 \\
\hline 7. Rice bran (\%) & 8 & 7 & 10 & 10 \\
\hline 8. Mineral (\%) & 1 & 1 & 1 & 1 \\
\hline 9. Molasses (\%) & 3 & 2 & 3 & 3 \\
\hline 10. Salt (\%) & 1 & 1 & 1 & 1 \\
\hline Total & 100 & 100 & 100 & 100 \\
\hline
\end{tabular}

Additional feed was given $5 \mathrm{~kg} / \mathrm{head} / \mathrm{day}$ and the method of administration was divided into two times, morning $(2.5 \mathrm{~kg})$ and afternoon $(2.5 \mathrm{~kg})$ day.

Table 2. Nutritional content of complete feed periods I and II

\begin{tabular}{clccccc}
\hline No. & \multicolumn{1}{c}{ Description } & $\begin{array}{c}\text { Water } \\
\text { content } \\
(\%)\end{array}$ & $\begin{array}{c}\text { Ash } \\
(\%)\end{array}$ & $\begin{array}{c}\text { Protein } \\
(\%)\end{array}$ & $\begin{array}{c}\text { Fat } \\
(\%)\end{array}$ & Crude fat $(\%)$ \\
\hline I. & Period I & & & & & \\
1. & Feed formulation I & 43.11 & 15.12 & 9.91 & 2.77 & 43.98 \\
2. & Feed formulation II & 44.28 & 14.23 & 8.44 & 2.80 & 45.64 \\
II. & Period II & & & & & \\
1. & Feed formulation I & 39.30 & 13.46 & 9.01 & 3.75 & 46.97 \\
2. & Feed formulation II & 38.44 & 14.30 & 7.92 & 5.70 & 46.90 \\
III. & Habits of breeders : & & & & & \\
1. & Rice straw & 10.00 & 16.00 & 4.02 & 5.21 & 58.49 \\
2. & Field grass & 15.00 & 14.00 & 5.00 & 12.78 & 81.92 \\
3. & Sugarcane leaves & 7.00 & 7.00 & 2.63 & 2.51 & 34.25 \\
\hline
\end{tabular}

\section{Collected data}

The data collected were: body weight, calf birth weight, and post partus estrus (first estrus after giving birth).

\section{Data analysis}

All observational data were tabulated and analyzed with simple statistics by calculating the average. The results of the next analysis are reported descriptively. 


\section{Results and Discussion}

\section{A. Ruminant Animal Feed}

Ruminants feed generally in the form of grass and legumes. Apart from grasses and legumes, agricultural, plantation and industrial waste can also be used as feed for ruminants. Agricultural waste that is often used as feed for ruminants, namely: rice bran and straw, stover, bran, and corn cob, and soybean stover, while plantation waste, namely: shoots and bagasse, leaves and palm kernel cake. Meanwhile, industrial waste is in the form of soy sauce dregs, corn dregs, and soybean meal. The availability of feed or feed ingredients depends on regional conditions and seasons. Thus, the availability of ruminant feed or feed ingredients for one area is different from another. In addition, its availability throughout the year is very volatile depending on the season, as happened in Megal Village, Pamotan District, Rembang Regency.

Sources of feed for ruminants in Megal Village, Pamotan District, Rembang Regency, namely: field grass and elephants, fresh and dry straw, sugarcane shoots, jaranan leaves, and gliricidia (Table 3). The availability of the feed throughout the year is very volatile because it is influenced by the seasons, namely the rainy and dry seasons. This season is very influential on cropping patterns of food crops and plantations, as well as the growth and development of forage fodder. Farmers in Megal Village in the rainy season plant rice so that fresh straw for cattle feed is available in abundance from March to May. The rice straw is then dried and stored for cattle feed so that dry straw is available from June to December. This rice straw should not be used as a sole feed because of its low protein content. According to Suningsih et al. (2019), the crude protein content of rice straw is $4 \%$. Yusriani et al. (2015) reported that giving $70 \%$ forage $+30 \%$ fermented straw + mineral blocks + concentrate provided optimal daily live weight gain.

Natural grass in Megal Village is available all year round and grows around teak forest plantations, rice fields, and dry fields (Table 3). The availability of this natural grass also fluctuates, in the rainy season it is abundant, while in the dry season it is very limited and of low quality. The crude protein content of natural grass is $7.05 \%$ (Wahyono et al., 2019). In addition to natural grass, elephant grass is also planted by farmers around dry land and forests. Elephant grass is only available in the rainy season because its growth and development requires sufficient water. The crude protein content of elephant grass is $12.75 \%$ (Jamaran 2006). Judging from the protein content, this elephant grass can be used as a single feed.

Sugarcane shoots in Megal Village are abundant from August to November (Table 3). The crude protein content of sugarcane shoots is 5.5\% (Khuluq, 2012). Provision of sugarcane shoots to livestock must be added with other feed ingredients because the protein content is low.

Jaranan leaves in Megal Village were available from January to June (Table 3). Jaranan tree is a tree plant whose leaves can be used for ruminant animal feed, usually planted around the yard of the house. The crude protein content of jaranan leaves is quite high, above the crude protein of grass, but below that of gliricidia. The crude protein content of jaranan leaves is $15.19 \%$ (Anonimus, 2014). 
Gliricidia in Megal Village is available from January to July (Table 3). Gliricidia plants are tree legumes that are usually planted as yard fences. The crude protein content of this plant is $24.68 \%$ (Daning \& Foekh, 2018) so that this plant can be used as a protein source feed. Provision for ruminants is about $5-10 \%$ of the total forage given to livestock.

Table 3. Availability of ruminant feed in Megal Village, Pamotan District, Rembang Regency

\begin{tabular}{|c|c|c|c|c|c|c|c|c|c|c|c|}
\hline Jan & Feb & March & April & Mei & June & July & Aug & Sept & Okt & Nov & Dec \\
\hline & & & & & & & & & & & \\
\hline & & & & & - & - & - & - & - & - & - \\
\hline- & - & & & & & & & & & & \\
\hline- & - & - & - & - & - & - & & & & & - \\
\hline & & & & & & - & - & - & - & - & - \\
\hline & & & & & & & - & - & - & - & - \\
\hline
\end{tabular}

Natural grass

Elephant grass

Fresh Straw

Sugarcane leaves
Dry straw

Jaranan leaves

Gliricidia

The availability of these fluctuating feed ingredients greatly affects the quantity and quality of feed given to livestock. During the rainy season the availability of forage will be abundant, while in the dry season forage will decrease so that this will affect the quantity and quality of feed given to livestock, as happened in Megal Village, Pamotan District, Rembang Regency.

Feeding of beef cows in Megal Village varies greatly, depending on the availability of feed. The feed given in January to May contained good enough nutrients to meet the needs of livestock, while for the months of June and July the nutrient content of the feed given had begun to decline. Meanwhile, the feed from August to December has low nutrient content, so this condition will cause problems for livestock reproduction.

Making fermented complete feed is one way that can be used to overcome this problem. When forage is abundant, a complete fermented feed can be made which can be stored for up to 4 months and can be given to livestock when needed either as supplementary feed or as basal feed. Complete feed is feed made from several feed ingredients which are a source of energy, protein, minerals, and vitamins so that the nutrient content is complete according to the needs of livestock. Making this complete feed can be done periodically once a week, once every two weeks or once a month depending on the availability of materials, a place to store, and the energy to make it. 


\section{Reproductive Appearance of Beef Cattle and Calf Birth Weight}

The quality of feed in the dry season is very low so that the nutrient content does not match the needs of livestock. Therefore, it is highly recommended to give additional feed to pregnant cows and after calving. The purpose of this supplementary feeding, namely: maintaining the condition of the mother's body, maintaining normal embryo growth, and accelerating postpartum estrus, as has been done in Megal Village, Pamotan District, Rembang Regency.

The provision of additional feed to pregnant beef cows (8-9 months) and after giving birth for 3 months in Megal Village, Pamotan District, Rembang Regency produced, namely:

1. Decreased body weight loss of beef cows (Table 4). The decrease in body weight was due to the fact that from August to November the quality of the feed provided was low so that the nutrient content was below the livestock's needs. The feed ingredients available in that month, namely: field grass, dry rice straw, and sugarcane shoots. The decrease in body weight of beef cows that were given additional feed was lower than those that were not given additional feed (Table 4).

2. The birth weight of calves from beef cows that were given additional feed was heavier than those that were not given additional feed (Table 4).

3. Postpartum estrus of beef cows that were given additional feed was faster than those that were not given additional feed (Table 5). Postpartum estrus of beef cattle fed with additional feed on the 109 day was as much as $80 \%$, while on the 150th day it was $60 \%$. Meanwhile, beef cows that were not given additional feed were $>180$ days.

This difference was due to the addition of $5 \mathrm{~kg} / \mathrm{head} / \mathrm{day}$ of additional feed. This additional feeding affects the amount of protein consumed. The protein consumed by beef cows that were given additional feed was more than those that were not given additional feed. Protein is used by the body for cell growth and development, replacing damaged body tissues, forming enzymes and hormones. Hardie (2020) reported that the protein in the rumen will be partially digested by rumen microbes into ammonia (NH3) and amino acids. These amino acids will be used by microbes to grow and reproduce. Amino acids, microbes, and undigested feed protein in the rumen will be a source of protein for ruminants. This protein source is digested and absorbed in the small intestine for the body's protein synthesis. Protein in the body is a very important compound because protein carries out most of the physiological functions of the body. Proteins in the body act as: 1) building blocks and replacements for damaged body tissues, 2) forming enzymes, hormones, and antibodies, and 3) regulating the flow of body fluids and dissolved substances into or out of body cells. Protein feed before being used in ruminants will go through several processes first, namely: 1) undergoing fermentation in the reticulo rumen, 2) undergoing hydrolysis digestion in the small intestine, and 3) undigested protein will be excreted with feces. Thus, this supplementary feeding will provide better performance of the cow and her calves, as reported by several other researchers. Lutfi et al. (2016) reported that Jabres cattle productivity was low due to limited feed. The production and reproduction performance of Jabres cows fed with supplemental feed were better than those not fed additional feed. Ratnawati et al. (2016) reported that management improvement technology by maintaining a parent body condition score $>3$ can improve the reproductive performance of Brahman cross cattle. 
Iswanto et al. (2017) reported that supplementary feeding to pregnant and post-calving PO cows can provide better birth weight, calving spacing and body size.

Tabel 4. The average development of body weight of beef cattle and calf birth weight in Megal Village, Pamotan District, Rembang Regency

\begin{tabular}{cccc}
\hline No. & $\begin{array}{c}\text { Livestock } \\
\text { Group }\end{array}$ & $\begin{array}{c}\text { Body Weight Development } \\
\text { Parent stock of beef cattle (kg/head/day) }\end{array}$ & $\begin{array}{c}\text { Calf Birth Weight } \\
\text { (kg/head) }\end{array}$ \\
\hline 1. & I & -1.119 & 26.52 \\
2. & II & -1.264 & 25.40 \\
3. & III & -2.316 & 24.26 \\
\hline
\end{tabular}

Livestock Group I : Group of cattle that were given supplementary feed formulation 1

Livestock Group II : Group of cattle that were given supplementary feed formulation 2

Livestock Group III : Group of livestock that is not given additional feed

The types and composition of ingredients for complete feed periods I and II used for supplementary feed for pregnant and post-pregnant beef cattle in Megal Village, Pamotan District, Rembang Regency are listed in Table 1. Materials used as protein sources for elephant grass, jaranan leaves, and gliricidia leaves, while the materials used as energy sources are rice bran. In addition, the material is also used as a source of minerals. Complete feeds are made according to the availability of materials in Megal Village. Complete feed crude protein content 7-10\%.

The nutrient content of complete feed used for supplementary feed in pregnant and postnatal beef cows in Megal Village, Pamotan District, Rembang Regency is listed in Table 2. The crude protein content of complete feed formulation I was higher than formulation II. This difference was caused by the complete feed of formulation I using elephant grass and gliricidia leaves which contain high crude protein.

Additional feeding with a higher protein content will result in better reproductive performance. The group of beef cows fed with supplementary feed formulation I showed $80 \%$ postpartum estrus on the 109th day, while $60 \%$ of those given supplementary feed formulation II on the 150th day. Meanwhile, those who were not given additional feed were $>180$ days.

Table 5. Percentage and timing of post partum estrus for beef cows in Megal Village, Pamotan District, Rembang Regency

\begin{tabular}{cccc}
\hline No. & $\begin{array}{c}\text { Livestock } \\
\text { Group }\end{array}$ & Parent stock of beef cattle (\%) & Time Estrus post Partus (day) \\
\hline 1. & I & 80 & 109 \\
2. & II & 60 & 150 \\
3. & III & 0 & $>180$ \\
\hline
\end{tabular}

Livestock Group I : Group of cattle that were given supplementary feed formulation 1 Livestock Group II : Group of cattle that were given supplementary feed formulation 2 Livestock Group III : Group of livestock that is not given additional feed 


\section{Conclusion}

Giving additional feed of $5 \mathrm{~kg} / \mathrm{head} /$ day to pregnant beef cows and after giving birth for 3 months can suppress the decrease in body weight of beef cattle when the availability of feed is limited, increase calf birth weight and accelerate postpartum estrus (first estrus after birth ). Supplementary feeding to pregnant beef cows and after giving birth is highly recommended, especially for areas where the availability of feed fluctuates.

\section{References}

Anonimus. 2014. Analisis Proksimat Daun Jaranan. http://diaryternak. blogspot.com /2014/04/laporan-praktikum-bpfr-perhitungan.html. Diakses 29 Juli 2020.

Daning DRA dan Foekh B. 2018. Evaluasi Produksi dan Kualitas Nutrisi pada Bagian Daun dan Kulit Kayu Calliandra callotirsus dan Gliricidia sepium. Sains Peternakan 16 (1): 7-11.

Hardie. 2020. Metabolisme Pakan pada Ternak Ruminansia. rumen protein. Diakses 07 Pebruari 2020.

Iswanto, Kurnianto H, dan Utomo B. 2017. Pemanfaatan Sumberdaya Pakan Lokal untuk Flushing Induk Sapi PO di Peternakan Rakyat. Prosiding Seminar Nasional Kesiapan Sumber Daya Pertanian dan Inovasi Spesifik Lokasi Memasuki Era Industri 4.0, BPTP Jawa Tengah 2017.

Jamaran N. 2006. Produksi Dan Kandungan Gizi Rumput Gajah (P. purpureum) Dan Rumput Raja (P. purpupoides) Yang Ditumpangsarikan Dengan Tanaman Jati. Jurnal Peternakan Indonesia 11(2):151-157.

Khuluq AD. 2012. Potensi Pemanfaatan Limbah Tebu sebagai Pakan Fermentasi Probiotik. Buletin Tanaman Tembakau, Serat \& Minyak Industri 4(1): 37-45.

Luthfi M, Adinata Y, dan Ratnawati D. 2016. Perbaikan Performans Produksi dan Reproduksi Sapi Jabres. Prosiding Seminar Nasional Inovasi Teknologi Pertanian. Banjarbaru, 20 Juli 2016.

Permentan. 2016. Upaya Khusus Percepatan Peningkatan Populasi Sapi dan Kerbau Bunting. Permentan no 48 tahun 2016. Kementerian Pertanian.

Ratnawati D, Indrakusuma DA, Affandhy L, Cowley LF, Mayberry D, Poppi D. 2016. Management Strategies to Improve Reproductive Performance of Brahman Cross Cattle (Bos indicus) in East Java, Indonesia. JITV 21 (4): 231-237.

Suningsih AN, Ibrahim W, Liandris O, dan Yulianti R. 2019. Kualitas Fisik dan Nutrisi Jerami Padi Fermentasi pada Berbagai Penambahan Starter. Jurnal Sain Peternakan Indonesia 14(2): 191-200.

Wahyono T, Jatmiko E, Firsoni, Hardani SNW, dan Yunita E. 2019. Evaluasi Nutrien dan Kecernaan In Vitro Beberapa Spesies Rumput Lapangan Tropis di Indonesia. Sains Peternakan 17 (2): 17-23.

Yusriani Y, Elviwirda dan M. Sabri M. 2015. Kajian Pemanfaatan Limbah Jerami Sebagai Pakan Ternak Sapi di Provinsi Aceh The Study of Rice Straw Utilization for Cattle Feed Supplement in Aceh Province. Jurnal Peternakan Indonesia 17 (2): 163-169. 